\title{
Impacts of future climate variability on hydrological processes in the upstream catchment of Kase River basin, Japan
}

\author{
Preeti Pokhrel ${ }^{1,2} \cdot$ Koichiro Ohgushi $^{3} \cdot$ Masafumi Fujita $^{4}$
}

Received: 9 November 2017 / Accepted: 9 January 2019 / Published online: 16 January 2019

(c) The Author(s) 2019

\begin{abstract}
The purpose of this study is to predict the hydrological responses to climate change in the upstream catchment of Kase River basin having an area of $225 \mathrm{~km}^{2}$ by using MIKE SHE model and GIS. Meteorological and hydrological data for the period of 5 years were available in Kase River basin. Average daily discharge data from 5-year period (1991-1995) were used for the calibration effort, and average daily discharge was measured at Kawakami station. The Nash-Sutcliffe efficiency, $\mathrm{NSE}=0.588$, suggests that the model can predict the runoff mechanism for different periods satisfactorily. To assess the climate change impacts, two scenarios were taken under consideration. The data generated from RCM 20 (Regional Climate Model) were utilized under scenario 1 to predict future period 2081-2100 in the river basin. On the other hand, CC-scenario 2 assumes an increase in average monthly air temperature about $3{ }^{\circ} \mathrm{C}$ and no change in precipitation in future at the end of twenty-first century. The results revealed that future climate variability under scenario 1 caused an increase of $408.16 \mathrm{~mm}$ in surface flow; $46.77 \mathrm{~mm}$ in terms of base flow and interflow; and an increase of $41.74 \mathrm{~mm}$ actual ET (evapotranspiration). The increase in surface runoff may be mostly due to increase in precipitation. Future climate variability under scenario 2 caused a decrease of $38.43 \mathrm{~mm}$ in surface flow; $2.25 \mathrm{~mm}$ in terms of base flow and interflow; and an increase of $46.62 \mathrm{~mm}$ actual ET. The decrease in surface runoff may be due to unchanged precipitation and increase in temperature.
\end{abstract}

Keywords GIS · MIKE SHE $\cdot$ Hydrological processes $\cdot$ Discharge $\cdot$ Climate change scenarios

\section{Introduction}

Japan lies in the northeast part of the Asian Mainland that surrounds Southeast Asian countries. Japan has relatively little area that is level and lowland, and most of the water resources to the lowland are supplied by mountainous river basin. Also, most of the forest area lies in the mountain regions and mountains tend to receive higher precipitation (Sawano et al. 2005). It is understood that river water

Preeti Pokhrel

17nd306s@vc.ibaraki.ac.jp

1 Graduate School of Science and Engineering, Saga University, 1 Honjo-Machi, Saga 840-8502, Japan

2 Major in Social Infrastructure System Science, Ibaraki University, 4-12-1 Nakanarusawa, Hitachi, Ibaraki 316-8511, Japan

3 Department of Civil Engineering and Architecture, Saga University, 1 Honjo-Machi, Saga 840-8502, Japan

4 Department of Civil, Architectural and Environmental Engineering, Ibaraki University, 4-12-1 Nakanarusawa, Hitachi, Ibaraki 316-8511, Japan is essential water resource in Japan and its efficient use is essential.

Global climate change is likely to cause rising sea level, more frequent heavy rainfall and severe droughts (MLIT 2016). To maintain the quality of environment and disaster prevention, it is better to understand possible climate change impacts on the hydrological processes in the countries like Japan, where water resources are limited. Drastic changes have taken place on a global scale in land-use patterns and climate in catchments with the continuous expansion of human development (Shi et al. 2013) as these changes could result in significant impacts on hydrological processes affecting precipitation, runoff processes and water resources (Arnell and Reynard 1996; Cuo et al. 2014; Haddeland et al. 2012; Pervez and Henebry 2015; Zhang et al. 2010; Wagner et al. 2013; Calder 1993; Im et al. 2003).

Climate change significantly affects hydrological conditions providing an assessment of ecohydrological effects (House et al. 2016). Most of the emission scenarios and model used focused on impacts of climate change on seasonal discharge and extreme flows (Yan et al. 2015). Some 
of the spatio-temporal change in hydrological processes may greatly influence the potential water resources availability (Liu et al. 2015). Few of them implemented an adaptive watershed management approach (Zhang 2008).

Kase River is one of the major rivers in Saga Prefecture, Japan. The river basin is located in western part of Japan, Kyushu Island (Fig. 1). The watershed is characterized in climatology as warm and temperate zone. Most of the precipitation $(\sim 58 \%)$ falls between June and September. The mean annual temperature in the river basin is $16.5^{\circ} \mathrm{C}$. The highest average monthly temperature is in July and August and lowest is in January. A part of Kase River basin is an agricultural area where irrigation plays a vital role in the downstream part of the basin. During 1987-2009, 3\% nonforest area was changed to forest area. Some structures like dam were also constructed during that period.

Several previous studies were carried out in this river basin among which some studies focused on prediction of dam construction impacts on annual and peak flow rates by using SWAT hydrological model (Supit and Ohgushi 2012). In those studies, groundwater flow was not described clearly. The Kase River has a relatively small basin and cannot supply enough water for the water demand of the river basin and of the Saga City. Disasters like flood and drought have become major problems in this area. The major causes are due to the changes in land use and climate. The factors

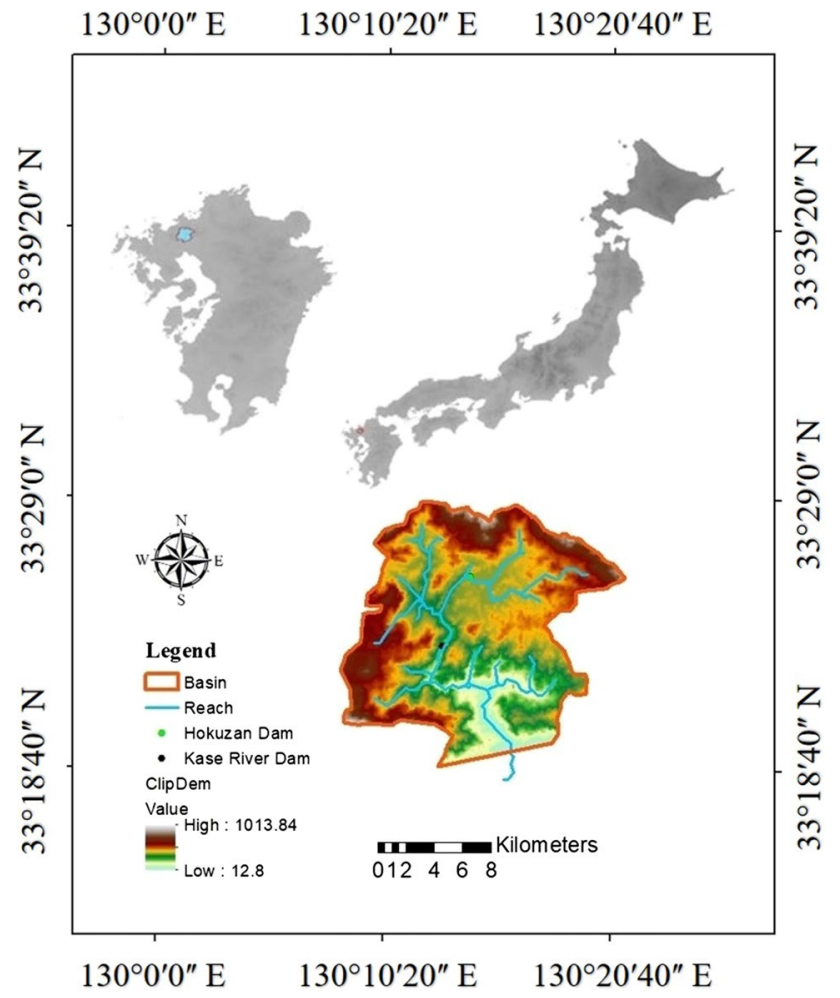

Fig. 1 Study area affecting river regime and related hydrological parameters are temperature increase, precipitation change and environmental change in the basin areas, including forests, rice and other fields. An increasing variation of precipitation will increase the variation of river discharge, resulting in extreme floods and droughts.

Unlike previous study, we focused all the hydrological components derived from mathematical model. The objective of this study was to quantify the variability in climate after 100 years by using RCM 20 results (Kurihara et al. 2005), simulate hydrological components to them and identify the impacts of such changes. This research is the first ever attempt to simulate all the hydrological processes by using integrated physically based hydrological model (MIKE SHE) in this catchment.

\section{Materials and methods}

\section{Watershed description}

Kase River is one of the major rivers in Saga Prefecture, originated in the Sefuri Mountains (elevation $912 \mathrm{~m}$ ) of Mitsuse, north of Saga City that flows through Saga Plain and pours into the Ariake Sea (Fig. 2). The total length of the river is about $57 \mathrm{~km}$, with catchment area about $368 \mathrm{~km}^{2}$. The population in the basin is about 130,000 people mostly concentrated in the downstream part. This prefecture has a big arable land and has regional granary for rice supply in Kyushu Island, Japan. In this study, an upstream catchment was focused with catchment area of $225 \mathrm{~km}^{2}$ that covers $61 \%$ of entire area of the basin. The elevation ranges from $12.8 \mathrm{~m}$ to above $1000 \mathrm{~m}$ from sea level. The watershed is characterized in climatology as warm and temperate zone. Precipitation mainly falls as a rain and the average annual rainfall is about $2376 \mathrm{~mm}$. The mean annual temperature in the river basin is $16.5^{\circ} \mathrm{C}$. The highest averages monthly temperature is in July and August and lowest is in January. Upstream catchment is generally covered by more than $80 \%$ of dry evergreen forest. Other area covers rice field, agriculture and buildings. During 1987-2009, 3\% non-forest area was changed to forest area. Floods are normally experienced during the rainy season, which has more intense rainfall caused by typhoons. The maximum discharge recorded at Kawakami water head was $55 \mathrm{~m}^{3} / \mathrm{s}$ during 1991 to 1995 , which occurred in July.

\section{Topographical and climatological data}

The digital elevation model (DEM) data with resolution of $5 \mathrm{~m}$ was obtained from Geospatial Information Authority (MLIT 2016). Using digital elevation model as input, Kase 


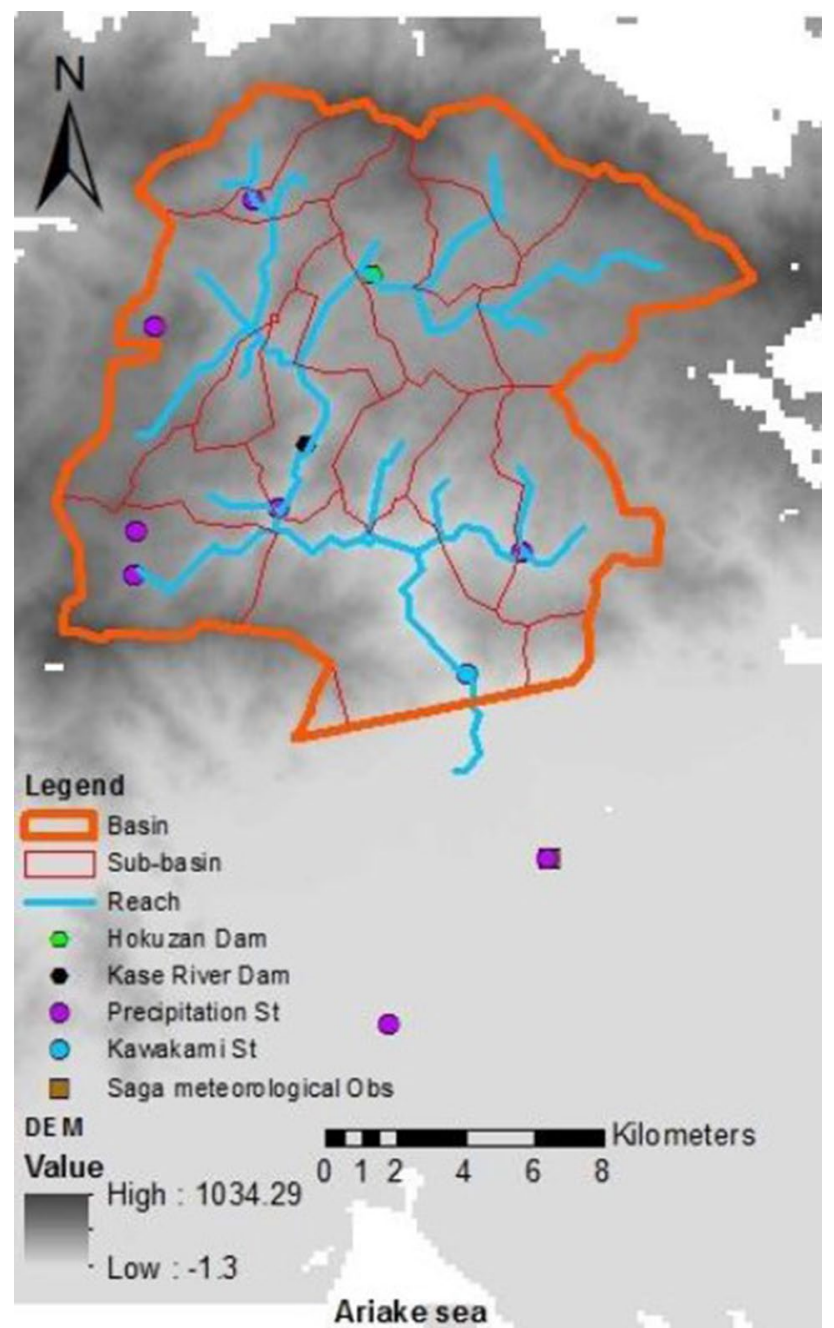

Fig. 2 Hydrological and meteorological stations

River basin was delineated by ArcGIS 10.3.1 to quantify the characteristics of the basin.

The land-use data of 1987 and 2009 were used in this study. The distribution of land use (Fig. 3) was classified from the Ministry of Land and Infrastructure, Japan (MLIT 2016).

The Kase River basin soil types were derived from Geological map of Japan (AIST 2003). After that the comparison was done with the soil map of Japan based on reclassification and digital soil map of the world to obtain the name of the soil types (Fig. 4) at river basin (FAO 2003).

The MIKE SHE model required rainfall and potential evapotranspiration as climatic input data. Rainfall records were collected from eight rain gauges within and adjacent to the watershed (Table 1, Fig. 2). Rainfall data were used as an input in each grid on a daily basis for model setup. It was spatially distributed according to a Thiessen polygon technique. A time series of potential evapotranspiration rates was also required for estimating soil evaporation and plant transpiration. Many variables changing that are impacting rates of potential evapotranspiration such as net radiation, vapor pressure, wind speed, air temperature and can be the most reasonable estimation for potential evapotranspiration (Donohue et al. 2010). Due to limited availability of data, potential evapotranspiration was calculated using the Hamon method (Xu and Singh 2001; Paparrizos et al. 2014). The equation requires air temperature, daylight hours and saturated water vapor density. These climate data were obtained from the Saga meteorological station (Table 2).

\section{Description of watershed model}

MIKE SHE is a deterministic, fully distributed, physically based hydrological and water quality modeling system (DHI 2014). It is capable of simulating hydrology and water quality processes occurring in watersheds and their underlying aquifers. MIKE SHE consists of major hydrological processes and includes process models for evapotranspiration, saturated flow, unsaturated flow and channel flow and their interactions. Each of these processes describes at various levels of spatial distribution and complexity, according to the objectives of the modeling study, the availability of field data and the modeler's choices (Butts et al. 2004).

Actual evapotranspiration (AET) is one of the components of this model. The simplified ET for the two-layer water balance method is based on a formulation presented in Yan and Smith (1994). The main purpose of the module is to calculate actual evapotranspiration and the amount of water that recharges the saturated zone. Detailed description of MIKE SHE modeling system can be found in MIKE SHE user's manual (DHI 2014) and associated publications (Abbott et al. 1986a, b; Refsgaard and Storm 1995).

The MIKE SHE model has been widely used to determine the hydrological responses in land-use changes and climate variability (Im et al. 2009; Sumarauw and Ohgushi 2012; Zhang 2008), the operation of irrigation (Jayatilaka et al. 1998; Singh et al. 1999), hydrological simulation of surface runoff and infiltration into saturated and unsaturated zones (Paparrizos and Maris 2017).

\section{Calibration of MIKE SHE model}

The model was setup for the basin upstream area $225 \mathrm{~km}^{2}$ that covers $61 \%$ of entire area of the Kase River basin. The input for the model includes the characterization of the vegetation cover and the physical soil properties. Due to the lack of availability of the vegetation data, constant parameters for leaf area index and root depth were considered in the model. In the case of soil properties, three different kinds of soils were described in the river basin having their own physical properties that include a constant infiltration capacity and the soil moisture contents at the wilting point, field capacity 
Fig. 3 Land-use map of upstream Kase River basin (1987)
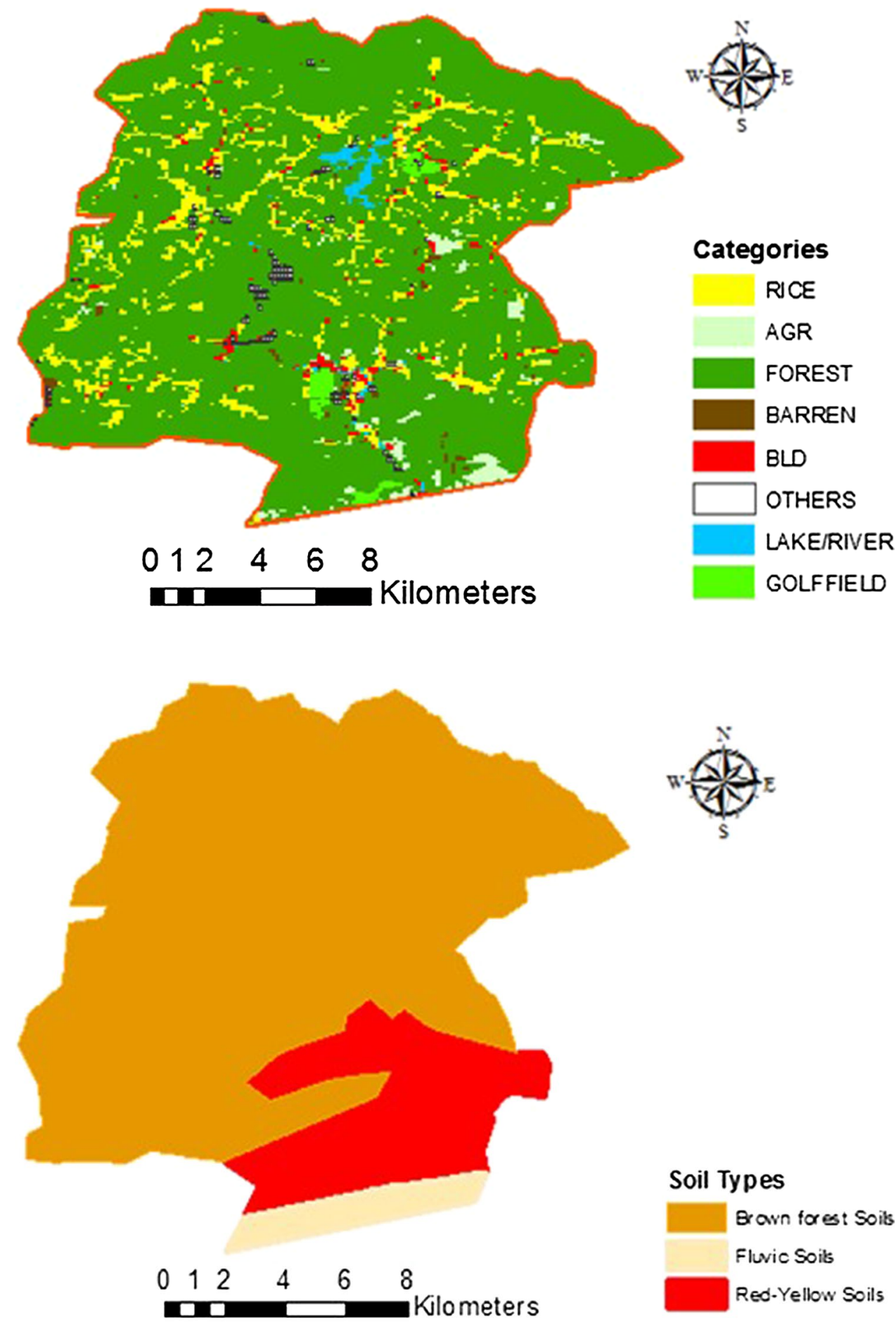

Fig. 4 Soil map of upstream Kase River basin 
Table 1 Meteorological stations

\begin{tabular}{lllll}
\hline Station & Latitude & Longitude & Elevation $(\mathrm{m})$ & $\begin{array}{l}\text { Average annual } \\
\text { rainfall }(\mathrm{mm})\end{array}$ \\
\hline Kase gawa & $33^{\circ} 14^{\prime} 21^{\prime \prime}$ & $130^{\circ} 14^{\prime} 38^{\prime \prime}$ & 17.2 & 1576 \\
Saga & $33^{\circ} 16^{\prime} 57^{\prime \prime}$ & $130^{\circ} 17^{\prime} 32^{\prime \prime}$ & 0 & 2422 \\
Nao & $33^{\circ} 21^{\prime} 45^{\prime \prime}$ & $130^{\circ} 17^{\prime} 01^{\prime \prime}$ & 162 & 2176 \\
Furuyu & $33^{\circ} 22^{\prime} 23^{\prime \prime}$ & $130^{\circ} 12^{\prime} 30^{\prime \prime}$ & 190 & 2421 \\
Udo & $33^{\circ} 27^{\prime} 10^{\prime \prime}$ & $130^{\circ} 11^{\prime} 58^{\prime \prime}$ & 360 & 1577 \\
Yanba & $33^{\circ} 25^{\prime} 12^{\prime \prime}$ & $130^{\circ} 10^{\prime} 10^{\prime \prime}$ & 540 & 2129 \\
Sugiyama & $33^{\circ} 22^{\prime} 00^{\prime \prime}$ & $130^{\circ} 09^{\prime} 52^{\prime \prime}$ & 580 & 2727 \\
Ichikawa & $33^{\circ} 21^{\prime} 20^{\prime \prime}$ & $130^{\circ} 09^{\prime} 48^{\prime \prime}$ & 420 & 2727 \\
\hline
\end{tabular}

where $P$ is precipitation in $\mathrm{mm}$, DIR is direct runoff in $\mathrm{mm}$; $\mathrm{RF}$ is basic runoff and intermediate runoff in $\mathrm{mm}$ and $\Delta S$ is change in storage in $\mathrm{mm}$.

The following statistics were used to determine whether to check the successful calibration/validation of the model. These indicators are following: the mean absolute error (MAE), the relative mean square error (RRMSE) and the coefficient of Nash-Sutcliffe efficiency (NSE) (Legates and McCabe 1999). The equations of the indicators are as follows:

MAE $=\frac{\sum_{i=1}^{n}\left|O_{i}-P_{i}\right|}{n}$

RRMSE $=\sqrt{\frac{\sum_{i=1}^{n}\left(O_{i}-P_{i}\right)^{2}}{n}} \frac{1}{\bar{O}}$

$\mathrm{EF}=1.0-\frac{\sum_{i=1}^{n}\left(O_{i}-P_{i}\right)^{2}}{\sum_{i=1}^{n}\left(O_{i}-\bar{O}\right)^{2}}$

where $O_{i}$ are the observed values, $P_{i}$ are the simulated values and $\bar{O}$ is the average of observed values.

The simulated result of hydrographs at Kawakami station is considered with minor differentiations as shown in
Table 3 Calibration results at Kawakami Station

\begin{tabular}{ll}
\hline Statistical index & $\begin{array}{l}\text { Calibration } \\
\text { period }(1 / 1 / 1991- \\
12 / 31 / 1995)\end{array}$ \\
\hline Average discharge $\left(\mathrm{m}^{3} / \mathrm{s}\right)$ & $13.80(14.37)^{*}$ \\
EF & 0.588 \\
MAE & 5.26 \\
RRMSE & 0.51 \\
\hline
\end{tabular}

*In bracket is the observed value

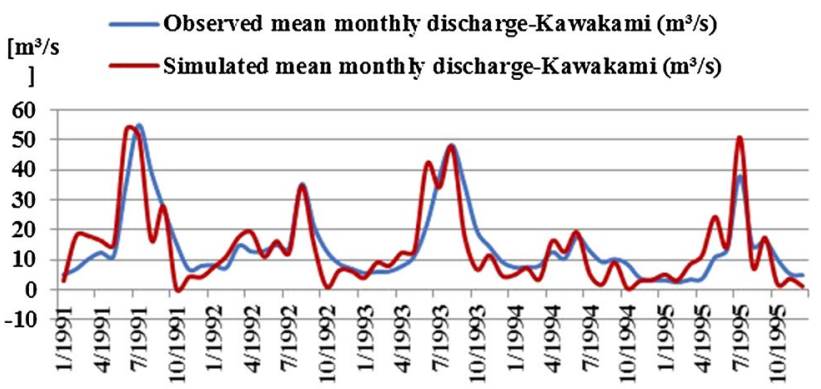

Fig. 5 Observed and simulated hydrographs at Kawakami station $\left(\mathrm{m}^{3} / \mathrm{s}\right)$

Table 3. Figure 5 shows the calibration result for flow at the basin during 1991-1995. The Nash-Sutcliffe efficiency $\mathrm{NSE}=0.588$ (Table 3) and $R^{2}=0.68$ (Fig. 6) suggest that the model can predict the runoff mechanism for different time periods satisfactorily. The $R^{2}$ value is a marker of strength from the correlation between the observed and simulated values. In some period, especially in winter months, the model underestimated. However, in other periods the model was able to simulate satisfactorily.

\section{Prediction of future climate trend using climate change scenarios}

a) CC-scenario 1 (RCM 20 under A2 scenario)

This scenario assumes a heterogeneous world; daily precipitation will increase during the warm season from June to September (Fig. 7), and air temperature will increase more than $2{ }^{\circ} \mathrm{C}$ in January, whereas summer temperature will be lower by about $1{ }^{\circ} \mathrm{C}$ than in winter in future (Fig. 8) at the end of twenty-first century. The data generated from RCM
Table 2 Climate and discharge data station

\begin{tabular}{lccclc}
\hline Station & Latitude & Longitude & Elevation $(\mathrm{m})$ & $\begin{array}{l}\text { Average annual } \\
\text { temperature }\left({ }^{\circ} \mathrm{C}\right)\end{array}$ & $\begin{array}{c}\text { Average annual } \\
\text { discharge }\left(\mathrm{m}^{3} / \mathrm{s}\right)\end{array}$ \\
\hline $\begin{array}{c}\text { Saga Meteoro- } \\
\text { logical. Obs. }\end{array}$ & $33^{\circ} 16^{\prime} 57^{\prime \prime}$ & $130^{\circ} 17^{\prime} 32^{\prime \prime}$ & 0.0 & $16.5^{\circ} \mathrm{C}$ & \\
\begin{tabular}{l} 
Kawakami \\
\hline
\end{tabular} & $33^{\circ} 19^{\prime} 50^{\prime \prime}$ & $130^{\circ} 16^{\prime} 03^{\prime \prime}$ & 12.16 & & 14.37 \\
\hline
\end{tabular}




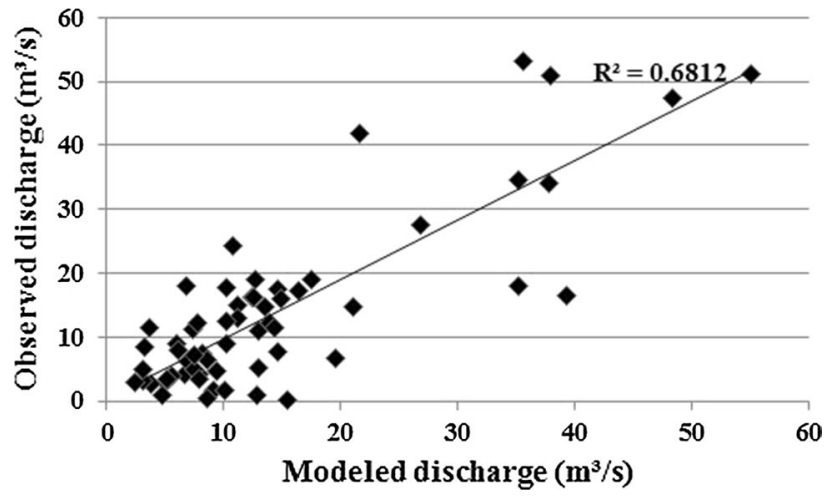

Fig. 6 Plot of correlation between observed and simulated discharges at Kawakami station $\left(\mathrm{m}^{3} / \mathrm{s}\right)$

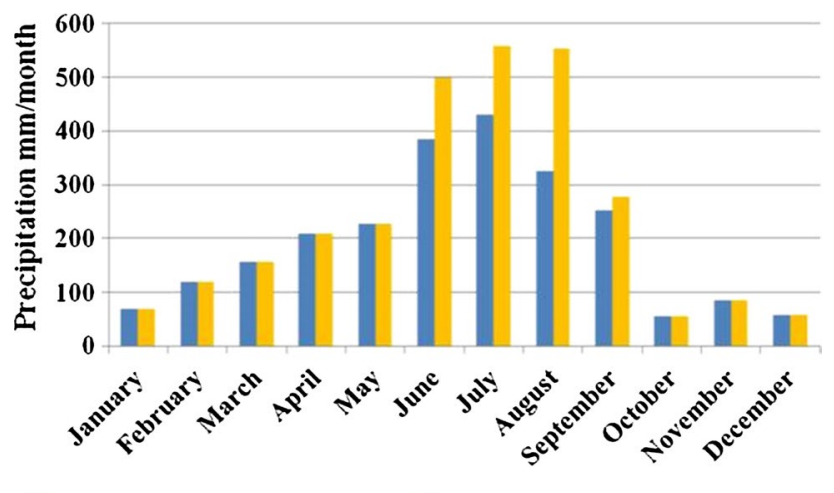

$\approx 5$ Year Average (1991-1995) $\quad$ RCM 20 under A2 scenario

Fig. 7 Precipitation change pattern after 100 years

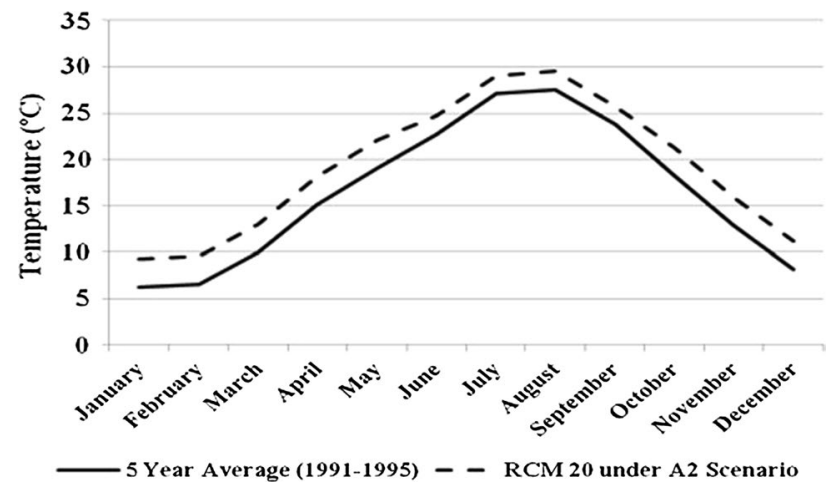

Fig. 8 Temperature change pattern after 100 years

20 model were utilized under scenario 1 to predict future period 2081-2100 in the river basin based on present climate (1991-1995).

b) CC-scenario 2 (temperature increase scenario)

This scenario assumes an increase in average monthly air temperature about $3{ }^{\circ} \mathrm{C}$ and no change in precipitation

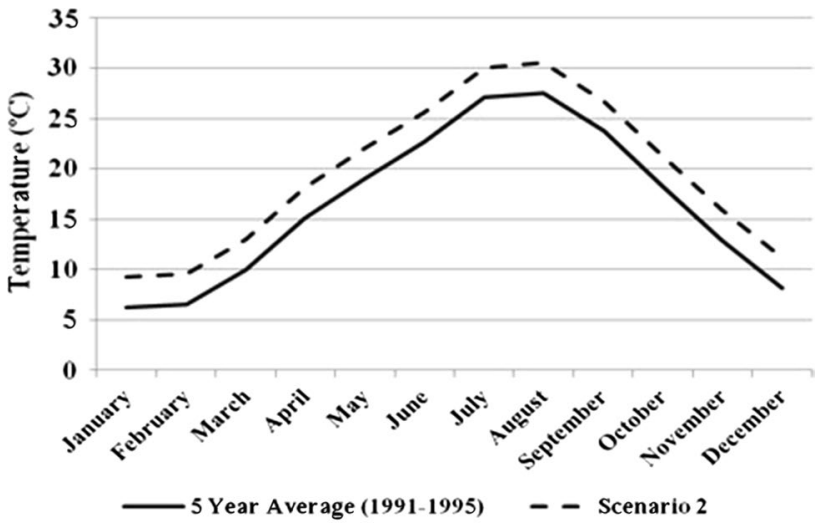

Fig. 9 Temperature change pattern after 100 years

in future at the end of twenty-first century (Fig. 9). This assumption was made by an author to compare the results on hydrological processes obtained by climate change scenario 1.

RCM 20 enabled to project the climate change to its details for the first time but is not perfect enough. Further efforts were needed to sophisticate the model for reproducing realistic present climate and accurate projection of future climate (Kurihara et al. 2005).

\section{Differentiated impact of land-use and climate change}

To quantify the impacts of land-use and future climate change on hydrological processes, 5-year average period (1991-1995) was chosen for present climate to predict for future period (2100). We selected this period according to the data available, and the data generated from RCM 20 is based on present climate (1981-2000). Land-use map for 1987 and 2009 was used to represent present and future periods. Altogether six simulations were performed using the calibrated MIKE SHE model: a combination of the land-use map for 1987 with the 5-year average climate data (1991-1995), land-use map for 2009 with the 5-year average climate data (1991-1995), land-use map for 1987 with the 5-year average climate data (scenario 1) and (scenario 2) and land-use map for 2009 with the 5-year average climate data (scenario 1) and (scenario 2). Finally, to compare the hydrological effects simulated results were used.

\section{Results}

\section{Land-use change}

Between 1987 and 2009, the Kase River basin experienced conversion of non-forest area to forest (Table 4, Fig. 10). 
Table 4 Land-use changes in Kase River basin between 1987 and 2009

\begin{tabular}{lrrr}
\hline Land use & \multicolumn{1}{c}{$\begin{array}{l}\text { } \\
\%\end{array}$} & \multicolumn{1}{c}{$\%$} & \multicolumn{1}{l}{$\begin{array}{l}\text { 1987-2009 } \\
\end{array}$} \\
\hline Rice & 11.11 & 9.21 & -1.90 \\
Agriculture & 2.10 & 1.97 & -0.13 \\
Forest & 81.78 & 84.44 & 2.67 \\
Waste land/Barren & 2.58 & 0.56 & -2.02 \\
Building & 1.21 & 1.56 & 0.35 \\
Others & 0.44 & 0.89 & 0.45 \\
Lake/river & 1.10 & 0.83 & -0.27 \\
Golf field & & 0.87 & 0.87 \\
\hline
\end{tabular}

The dominant land area in 1987 was forest, which covered $81.78 \%$ of the upstream watershed, followed by rice field $11.11 \%$, agriculture $2.10 \%$ and barren $2.58 \%$. Urban area played only a minor role $1.21 \%$ and also water and others less than $2 \%$ in year 1987. In 2009, urban area covered $1.56 \%$ of the upstream basin, slight increase from 1987. Forest increased about $3 \%$ within 22 -year period. Rice field and barren land decreased by $2 \%$ and agriculture land slightly decreased.

\section{Changes in temperature, precipitation and potential evapotranspiration}

In 5-year average period (1991-1995), the average temperature was $16.5^{\circ} \mathrm{C}$. Table 5 shows the average value for temperature, precipitation and potential evapotranspiration under different scenarios. The average temperature increases by $2.5{ }^{\circ} \mathrm{C}$ in the case of scenario 1 and about $3{ }^{\circ} \mathrm{C}$ for scenario 2 . The average precipitation increased by $20 \%$ in scenario 1 . Potential evapotranspiration was increased by about $16 \%$ in scenario 1 and about $20 \%$ in the case of scenario 2 . This result is due to the increase in temperature in scenario 2 by $0.5^{\circ} \mathrm{C}$ than scenario 1 .

\section{Differentiated impact of land use/climate variability on hydrological processes}

To describe the detailed impacts of the land use and climate variability on hydrological processes, some key factors are compared under different scenarios. The results are listed in Tables 6 and 7 .

In terms of land-use changes, the major changes were increase in forestland and decrease in barren land. It resulted in an increase in the mean annual evapotranspiration $(1.54 \mathrm{~mm})$ whereas there were no significant changes in surface flow and base flow in Kase Watershed. The increased ET could be a result of increased area of forest.
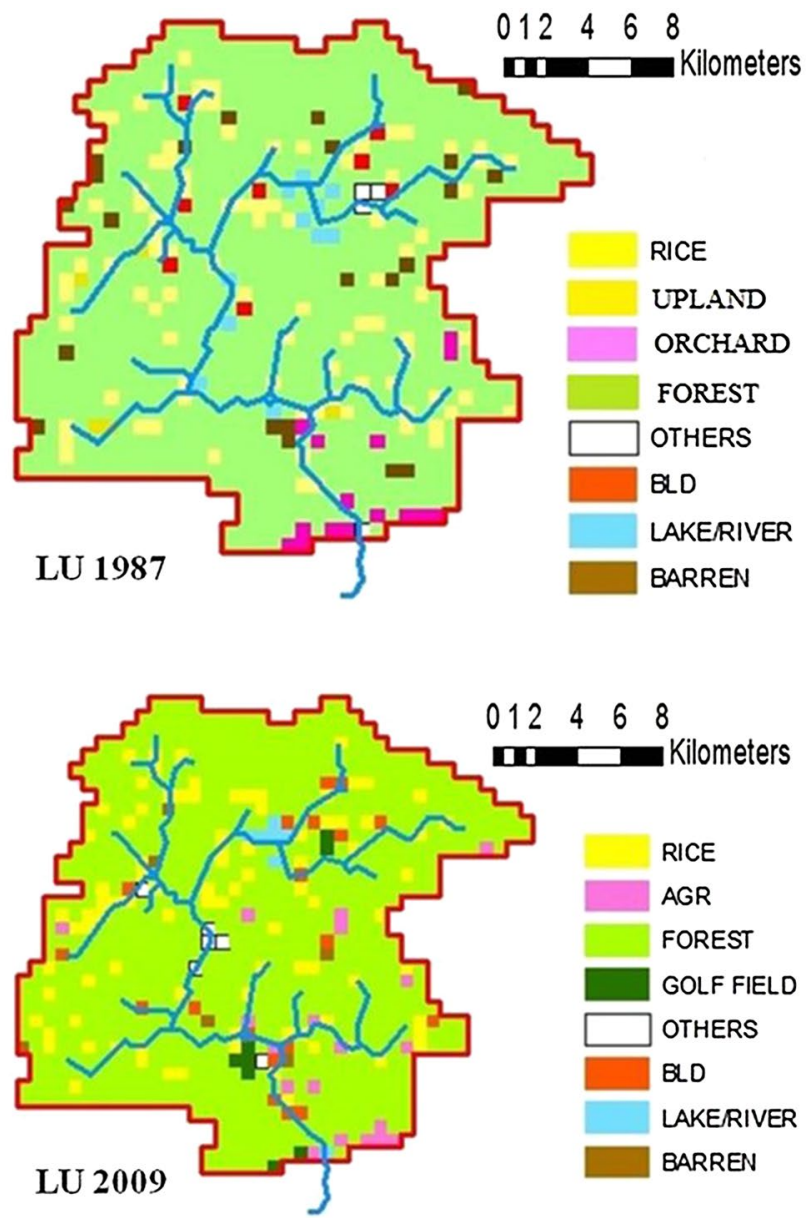

Fig. 10 Spatially distributed land-use maps for 1987 and 2009

Table 5 Changes in average value for temperature, precipitation and Pot.ET

\begin{tabular}{lccc}
\hline & $\begin{array}{l}\text { 5-year average } \\
\text { period (1991- } \\
\text { 1995) }\end{array}$ & Scenario 1 & Scenario 2 \\
\hline Temperature $\left({ }^{\circ} \mathrm{C}\right)$ & 16.5 & 19.0 & 19.5 \\
Precipitation $(\mathrm{mm})$ & 2376.0 & 2873.63 & 2376.0 \\
Pot.ET $(\mathrm{mm})$ & 266.92 & 310.26 & 321.50 \\
\hline
\end{tabular}

Future climate variability under scenario 1 caused an increase of $408.16 \mathrm{~mm}$ in surface flow; $46.77 \mathrm{~mm}$ in terms of base flow and interflow; and an increase of $41.74 \mathrm{~mm}$ actual ET. The increase in surface runoff may be mostly due to increase in precipitation. Therefore, annual temperature increased by about $3{ }^{\circ} \mathrm{C}$ from Jan to May, October to December and about $2{ }^{\circ} \mathrm{C}$ in summer resulting in a significant increase in actual ET.

Future climate variability under scenario 2 caused a decrease of $38.43 \mathrm{~mm}$ in surface flow; $2.25 \mathrm{~mm}$ in terms of base flow and interflow; and an increase of $46.62 \mathrm{~mm}$ actual 
Table 6 Hydrological simulations results under different scenarios

\begin{tabular}{llllll}
\hline Climate change impact & $\begin{array}{l}\text { Average annual } \\
\text { precipitation } \\
(\mathrm{mm})\end{array}$ & $\begin{array}{l}\text { Average } \\
\text { annual AET } \\
(\mathrm{mm})\end{array}$ & $\begin{array}{l}\text { Average } \\
\text { annual DIR } \\
(\mathrm{mm})\end{array}$ & $\begin{array}{l}\text { Average } \\
\text { annual RF } \\
(\mathrm{mm})\end{array}$ & $\begin{array}{l}\text { Average } \\
\text { annual DS } \\
(\mathrm{mm})\end{array}$ \\
\hline 5 year avg (1991-1995) & 2376.0 & 254.68 & 1935.72 & 220.45 & 0.16 \\
Land use & 2376.0 & 256.22 & 1936.44 & 221.11 & 0.15 \\
Scenario 1 & 2873.63 & 298.34 & 2344.41 & 268.01 & 0.17 \\
Scenario 2 & 2376.0 & 303.57 & 1898.09 & 219.03 & 0.15 \\
\hline
\end{tabular}

Table 7 Impacts of land-use/ future climate changes on hydrological processes

\begin{tabular}{|c|c|c|c|c|c|c|c|c|c|c|}
\hline \multirow[t]{3}{*}{ Hydrological processes } & \multicolumn{4}{|c|}{ Both change } & \multirow{2}{*}{\multicolumn{2}{|c|}{$\begin{array}{l}\text { Land use } \\
\text { contribu- } \\
\text { tion }\end{array}$}} & \multicolumn{4}{|c|}{ Climate contribution } \\
\hline & \multicolumn{2}{|c|}{ Scenario 1} & \multicolumn{2}{|c|}{ Scenario 2} & & & \multicolumn{2}{|c|}{ Scenario 1} & \multicolumn{2}{|c|}{ Scenario 2} \\
\hline & $\mathrm{mm}$ & $\%$ & $\mathrm{~mm}$ & $\%$ & $\mathrm{~mm}$ & $\%$ & $\mathrm{~mm}$ & $\%$ & $\mathrm{~mm}$ & $\%$ \\
\hline Surface runoff & 408.69 & 21.0 & -37.63 & -2.0 & 0.72 & 0.04 & 408.16 & 21.0 & -38.43 & -2.0 \\
\hline Runoff(I.F+B.F) & 47.56 & 21.0 & -1.42 & -0.64 & 0.66 & 0.30 & 46.77 & 21.0 & -2.25 & -1.0 \\
\hline Actual ET & 43.66 & 17.0 & 48.89 & 19.0 & 1.54 & 0.60 & 41.74 & 16.0 & 46.62 & 18.0 \\
\hline
\end{tabular}

ET. The decrease in surface runoff may be due to unchanged precipitation and increase in temperature. Therefore, average annual temperature increased by about $3{ }^{\circ} \mathrm{C}$ in all months causing significant increase in actual ET.

\section{Discussions}

It has been shown that the assessments of the impacts of climate change on water resources depend on the PET methods applied (Arnell 1999; Bae et al. 2011; Kay and Davies 2008). The assessment of evaporative demand trends depends on factors such as wind speed, humidity, solar radiation and air temperature. Precise analysis of atmospheric evaporative demand (AED) requires average air temperature (Milly and Dunne 2011), amount of solar radiation (Wild 2009), vapor pressure (Willett et al. 2008) and changes in wind speed (McVicar et al. 2012). However, in this study, we calculate PET by using Hamon method for both scenarios due to limited availability of data.

In terms of monthly distribution of the impacts of climate variability on the hydrological processes under scenario 1 for the period 2100 (Fig. 11), surface runoff increased in June to August due to significant increase in rainfall in those 4 months. The unchanged rainfall in dry season compared to wet season and increase in temperature in the same month resulted in a significant decrease of base flow and interflow at the same periods. A remarkable increase in precipitation from June to September induced a significant increase in groundwater flow at the same periods. For the actual ET, though the temperature increased from January to April by $3{ }^{\circ} \mathrm{C}$ remarkably, the actual ET had no significant change due to unchanged rainfall in those periods.

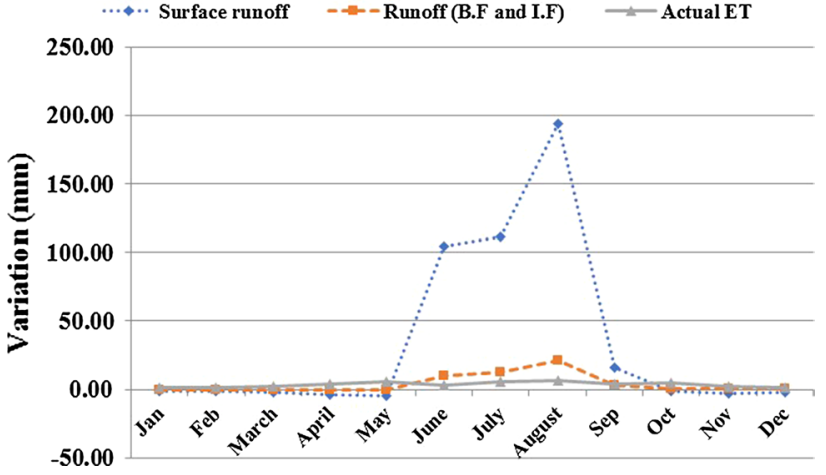

Fig. 11 Change in hydrological components in Kase River after 100 years under CC-scenario 1

For the case of scenario 2 for the period 2100 (Fig. 12), surface runoff decreased in all months due to significant increase in temperature in those months. The unchanged rainfall in dry season and wet season and increase in temperature in the same month resulted in a significant decrease in surface runoff at the same periods. A remarkable increase in temperature in all months induced a significant decrease in groundwater flow at the same periods. For the actual ET, due to the temperature increase from January to Dec by $3{ }^{\circ} \mathrm{C}$, the actual ET had increased significantly from June to September as compared to scenario 1 . This is due to the fact that scenario 1 and scenario 2 have the same temperature change pattern from Jan to May and October to December.

Increased atmospheric $\mathrm{CO}_{2}$ levels caused vegetation changes such as increases in rooting depth, which influences stream flow generation processes. Base flow represents the total outflow of all upstream riparian aquifers 


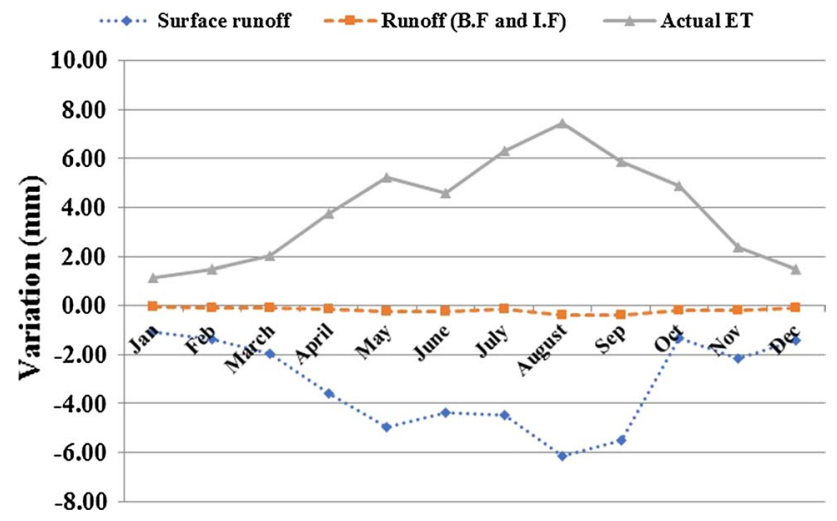

Fig. 12 Change in hydrological components in Kase River after 100 years under $\mathrm{CC}$-scenario 2

(Aksoy and Wittenberg 2011) and depends on water availability (precipitation and actual evapotranspiration), vegetation (land-use and functional $\mathrm{CO}_{2}$-driven changes (Trancoso et al. 2017)).

\section{Conclusions}

MIKE SHE model proved to be useful tool for assessing the effects of environmental changes including land use and climate variability in Kase Watershed. The Nash-Sutcliffe efficiency NSE $=0.588$ suggests that the model can predict the runoff mechanism for different periods satisfactorily. In some period, especially in winter months, the model underestimated. However, in other periods the model was able to simulate satisfactorily. Mathematical model like MIKE SHE requires many data for simulation. Furthermore, in the past 22 years land-use changes have occurred in this watershed. The major changes were the increase in forest land (3\%) and decrease in barren land.

The combined effect of these changes increased surface runoff and evapotranspiration. Changes in temperature and precipitation had increased surface runoff and evapotranspiration, whereas change in temperature only had decreased surface runoff in the watershed. Climate variability played a dominant role in this watershed.

In the mathematical model like MIKE SHE, there are many parameters, which should be considered during calibration. In this research, due to the site condition and availability of data some parameters are taken from references. Some parameters like vegetation data were kept constant while the time series data were not considered in the model. Overall, the differentiated impacts of land-use/ climate variability on hydrological processes revealed that even a small value could alter hydrological components in the river basin.
Acknowledgements The author would like to thank Makoto Hada and Takahiro Kazama marketing manager of Mike by DHI products for the guidance on software for author to complete her Master Thesis.

Open Access This article is distributed under the terms of the Creative Commons Attribution 4.0 International License (http://creativeco mmons.org/licenses/by/4.0/), which permits unrestricted use, distribution, and reproduction in any medium, provided you give appropriate credit to the original author(s) and the source, provide a link to the Creative Commons license, and indicate if changes were made.

\section{References}

Abbott M, Bathurst J, Cunge J, O'connell P, Rasmussen J (1986a) An introduction to the European hydrological system-systeme hydrologique Europeen, "SHE", 2: structure of a physically-based, distributed modelling system. J Hydrol 87(1-2):61-77

Abbott MB, Bathurst JC, Cunge JA, O'Connell PE, Rasmussen J (1986b) An introduction to the European hydrological systemsysteme hydrologique Europeen, "SHE", 1: history and philosophy of a physically-based, distributed modelling system. J Hydrol 87(1-2):45-59

AIST (2003) Geological map of Japan. https://pubs.usgs.gov/ of/2008/1385/pdf/igawa.pdf

Aksoy H, Wittenberg H (2011) Nonlinear baseflow recession analysis in watersheds with intermittent streamflow. Hydrol Sci J-J des Sci Hydrol 56(2):226-237

Arnell NW (1999) A simple water balance model for the simulation of streamflow over a large geographic domain. J Hydrol 217(3):314-335

Arnell N, Reynard N (1996) The effects of climate change due to global warming on river flows in Great Britain. J Hydrol 183(3-4):397-424

Bae D-H, Jung I-W, Lettenmaier DP (2011) Hydrologic uncertainties in climate change from IPCC AR4 GCM simulations of the Chungju Basin, Korea. J Hydrol 401(1):90-105

Butts MB, Payne JT, Kristensen M, Madsen H (2004) An evaluation of the impact of model structure on hydrological modelling uncertainty for streamflow simulation. J Hydrol 298(1):242-266

Calder IR (1993) Hydrologic effects of land-use change, chapter I3. In: Maidment DR (ed) Handbook of hydrology. McGraw-Hill, New York

Cuo L, Zhang Y, Zhu F, Liang L (2014) Characteristics and changes of streamflow on the Tibetan Plateau: a review. J Hydrol Reg Stud 2:49-68

DHI (Danish Hydraulic Institute) (2014) MIKE SHE user guide and techinal reference manual. DHI Software, Denmark

Donohue RJ, McVicar TL, Roderick M (2010) Assessing the ability of potential evaporation formulations to capture the dynamics in evaporative demand within a changing climate. J Hydrol 386:186197. https://doi.org/10.1016/j.jhydrol.2010.03.020

FAO (2003) The digital soil map of the world. Food Agric Org U N Version 3:6

Haddeland I et al (2012) Effects of climate model radiation, humidity and wind estimates on hydrological simulations. Hydrol Earth Syst Sci 16(2):305-318

House A, Thompson J, Acreman M (2016) Projecting impacts of climate change on hydrological conditions and biotic responses in a chalk valley riparian wetland. J Hydrol 534:178-192

Im S, Brannan KM, Mostaghimi S (2003) Simulating hydrologic and water quality impacts in an urbanizing watershed ${ }^{1}$. JAWRA J Am Water Resour Assoc 39(6):1465-1479 
Im S, Kim H, Kim C, Jang C (2009) Assessing the impacts of land use changes on watershed hydrology using MIKE SHE. Environ Geol 57(1):231

Jayatilaka C, Storm B, Mudgway L (1998) Simulation of water flow on irrigation bay scale with MIKE-SHE. J Hydrol 208(1-2):108-130

Kay A, Davies H (2008) Calculating potential evaporation from climate model data: a source of uncertainty for hydrological climate change impacts. J Hydrol 358(3):221-239

Kurihara K et al (2005) Projection of climatic change over Japan due to global warming by high-resolution regional climate model in MRI. SOLA 1:97-100

Legates DR, McCabe GJ (1999) Evaluating the use of "goodness-offit" measures in hydrologic and hydroclimatic model validation. Water Resour Res 35(1):233-241

Liu W et al (2015) Impacts of climate change on hydrological processes in the Tibetan Plateau: a case study in the Lhasa River basin. Stoch Environ Res Risk Assess 29(7):1809-1822

McVicar TR et al (2012) Global review and synthesis of trends in observed terrestrial near-surface wind speeds: implications for evaporation. J Hydrol 416:182-205

Milly PC, Dunne KA (2011) On the hydrologic adjustment of climatemodel projections: the potential pitfall of potential evapotranspiration. Earth Interact 15(1):1-14

MLIT, Japan (2016) Ministry of land, infrastructure, transport and tourism. Retrieved from www.mlit.go.jp/index_e.html

Paparrizos S, Maris F (2017) Hydrological simulation of Sperchios River basin in Central Greece using the MIKE SHE model and geographic information systems. Appl Water Sci 7(2):591-599

Paparrizos S, Maris F, Matzarakis A (2014) Estimation and comparison of potential evapotranspiration based on daily and monthly data from sperchios valley in central Greece. Glob NEST J 16(1):204-217

Pervez MS, Henebry GM (2015) Assessing the impacts of climate and land use and land cover change on the freshwater availability in the Brahmaputra River basin. J Hydrol Reg Stud 3:285-311

Refsgaard JC, Storm B (1995) Mike she. Comput Models Watershed Hydrol 1:809-846

Sawano S, Komatsu H, Suzuki M (2005) Differences in annual precipitation amounts between forested area, agricultural area, and urban area in Japan. J Jpn Soc Hydrol Water Res 18(4):435-440

Shi P et al (2013) Effects of land-use and climate change on hydrological processes in the Upstream of Huai River, China. Water Resour Manag 27(5):1263-1278

Singh R, Refsgaard J, Yde L (1999) Application of irrigation optimisation system (IOS) to a major irrigation project in India. Irrig Drain Syst 13(3):229-248
Sumarauw JSF, Ohgushi K (2012) Analysis on curve number, land use and land cover changes and the impact to the peak flow in the Jobaru River Basin, Japan. Int J Civ Environ Eng IJCEE-IJENS 12(02):17-23

Supit C, Ohgushi K (2012) Dam construction impacts on stream flow and nutrient transport in Kase River Basin. Int J Civ Environ Eng 12(3): $1-5$

Trancoso R, Larsen J, McVicar T, Phinn S, Mcalpine CA (2017) $\mathrm{CO} 2$ - vegetation feedbacks and other climate changes implicated in reducing baseflow. Geophys Res Lett. https://doi. org/10.1002/2017gl072759

Wagner P, Kumar S, Schneider K (2013) An assessment of land use change impacts on the water resources of the Mula and Mutha Rivers catchment upstream of Pune, India. Hydrol Earth Syst Sci 17(6):2233-2246

Wild M (2009) Global dimming and brightening: a review. J Geophys Res Atmos 114(D00D16): 1-31

Willett KM, Jones PD, Gillett NP, Thorne PW (2008) Recent changes in surface humidity: development of the HadCRUH dataset. J Clim 21(20):5364-5383

Xu CY, Singh V (2001) Evaluation and generalization of temperature-based methods for calculating evaporation. Hydrol Process 15(2):305-319

Yan J, Smith KR (1994) Simulation of integrated surface water and ground water systems-model formulation1. JAWRA J Am Water Resour Assoc 30(5):879-890

Yan D, Werners SE, Ludwig F, Huang HQ (2015) Hydrological response to climate change: the Pearl River, China under different RCP scenarios. J Hydrol Reg Stud 4:228-245

Zhang $\mathrm{Z}$ et al (2008) Evaluation of the MIKE SHE model for application in the Loess Plateau, China ${ }^{1}$. JAWRA J Am Water Resour Assoc 44(5):1108-1120

Zhang Q, Xu C-Y, Zhang Z, Chen YD (2010) Changes of atmospheric water vapor budget in the Pearl River basin and possible implications for hydrological cycle. Theoret Appl Climatol 102(1-2):185-195

Publisher's Note Springer Nature remains neutral with regard to jurisdictional claims in published maps and institutional affiliations. 